\title{
Estrela que vem do Norte: os baianos na umbanda de São Paulo ${ }^{1}$
}

\author{
Alice Costa Macedo \\ José Francisco Miguel Henriques Bairrão ${ }^{2}$ \\ Universidade de São Paulo, Ribeirão Preto-SP, Brasil
}

\begin{abstract}
Resumo: Os baianos da umbanda compõem uma categoria de espíritos associada a personagens tipicamente nordestinos. Este estudo visou caracterizar a categoria espiritual baiano na umbanda do Sudeste e desvendar como o panteão incorpora vivências humanas e tipos sociais. Recorreu-se à análise da literatura, observação participante e entrevistas com médiuns em transe. Colaboraram médiuns e dirigentes de terreiros do estado de São Paulo. Para a análise dos dados utilizou-se o conceito psicanalítico de significante. As narrativas dos baianos revelaram justaposições com aspectos da cultura nordestina, sugerindo que há uma transmutação de cenas regionais em metonímias e metáforas que se recombinam de modo a não haver uma reflexão imediata de tipos socialmente dados. Esses significantes materializam-se nos rituais, mas também em narrativas ricas em oxímoros, de modo a possibilitar a expressão do contraditório e a proporcionar símbolos religiosos nos quais o humano, paradoxal e conflituoso, possa se reconhecer.
\end{abstract}

Palavras-chave: umbanda, metáfora, psicanálise, cultura afro-brasileira.

\section{Star that comes from the North: the Baianos of the Umbanda sect in São Paulo}

\begin{abstract}
The Baianos of the Umbanda comprise a category of spirits associated with characters typical from the Brazilian Northeast. This study characterizes the spiritual category Baiano in the practice of Umbanda in the Southeast and uncovers how the pantheon incorporates human experiences and social types. Literature was consulted and data were collected through participative observation and interviews with medians in trances. Terreiros (places where the rituals occur) from the state of São Paulo, Brazil collaborated. The narratives revealed aspects that overlap those from the culture of the people of the northeast, suggesting there is a transmutation of regional scenes in metonymies and metaphors that are recombined so that one does not immediately reflect upon types that are socially determined. These meanings are materialized in rituals and in narratives rich in oxymorons, as well, enabling one to express contradictions and provide religious symbols in which the human, paradoxical and conflictive elements can be recognized.
\end{abstract}

Keywords: umbanda, metaphor, psychoanalysis, Afro-Brazilian culture.

\section{Estrella que viene del Norte: los baianos en la umbanda de São Paulo}

\begin{abstract}
Resumen: Los baianos de la umbanda componen una categoría de espíritus asociada a personajes típicamente nordestinos. Mediante este estudio se intenta caracterizar la categoría espiritual "baiano" en la umbanda del Sudeste y aclarar de qué forma el panteón incorpora las existencias humanas y los tipos sociales. Fueron usados análisis de la literatura, observación participante y entrevistas con los médiuns en trance. Fue utilizado el "método etnográfico" junto a la "escucha participativa". Hubo colaboración de Terreiros del estado de Sao Paulo. Para el análisis de los datos fue utilizado el "concepto psicoanalítico de significante". Las narrativas míticas de los baianos revelaran yuxtaposiciones de escenas regionales en metonimias y metáforas que se mezclan, haciendo con que no haya una reflexión inmediata acerca de los tipos socialmente dados. Esos significantes se materializan en los rituales pero también en las narrativas, ricas en oxímoros, de manera a posibilitar la expresión de la contradicción y a propiciar símbolos religiosos en que se pueda reconocer el humano, paradoxal y conflictivo.
\end{abstract}

Palabras clave: umbanda, metáfora, psicoanálisis, cultura afro-brasileña.

Em sua trajetória histórica, o nordestino resiste para se manter como um grupo social culturalmente coeso. Sua história é povoada por lutas, batalhas, atos de bravura e valentia, sendo a cultura nordestina gerada no bojo desse processo (Assunção, 1999). Certamente não é por coincidência ou

\footnotetext{
${ }^{1}$ Este texto foi revisado seguindo o Acordo Ortográfico da Língua Portuguesa (1990), em vigor a partir de $1^{\circ}$ de janeiro de 2009. Este trabalho contou com apoio da FAPESP, CAPES e CNPq.

${ }^{2}$ Endereço para correspondência:

Prof. Dr. José Francisco Miguel Henriques Bairrão. Laboratório de Etnopsicologia. Universidade de São Paulo. Faculdade de Filosofia, Ciências e Letras de Ribeirão Preto. Departamento de Psicologia. Av. Bandeirantes, 3900. CEP 14.040-901. Ribeirão Preto-SP, Brasil. E-mail: jfbairrao@ffclrp.usp.br
}

mero acaso que aspectos de coragem e insurgência figuram nas narrativas e construções míticas de espíritos e entidades religiosas em rituais populares de possessão, tais como a umbanda. Mudanças do contexto social podem influenciar transformações significativas no cenário dos rituais umbandistas, a exemplo do surgimento de novos personagens em seu panteão religioso, uma das questões que será tratada a seguir neste artigo.

Do mesmo modo, Mageo $(1996,2002)$ destaca que em Samoa tanto os sonhos dos habitantes da ilha quanto seus rituais de possessão são capazes de delinear precisamente como e onde o passado penetra o presente. Segundo ela, frequentemente os espíritos possuidores dão corpo a vozes de eras históricas específicas. 
Esta hipótese mostrou-se bastante frutífera para o presente estudo, na medida em que as narrativas dos baianos revelam justaposições com aspectos históricos do Nordeste, sugerindo que há, também neste caso, a possibilidade de consideração de um cenário sócio-histórico concreto, vivo no universo subjetivo de médiuns umbandistas, como significante - na acepção lacaniana do termo.

A psicanálise lacaniana possibilita uma escuta de marcas significantes de "ser baiano", que podem aparecer concretamente em rituais (em dança, ritmo, cores, sons, sabores e utensílios) e também na forma de seu estilo linguístico, em enredos míticos que se compõem em narrativas. De fato o conceito lacaniano de significante não está associado ao estritamente verbal. Ao contrário, essa noção psicanalítica traz em si a inscrição no corpo, a marca do vivencial. Em consonância, o "ser baiano" revela-se através de um impacto estético, de modo que uma sensação se torna um ato significativo e produz sentido. Identicamente, apetrechos e alimentos usados nos rituais também assumem valor metafórico-metonímico.

\section{Os baianos da umbanda}

Os baianos da umbanda compõem uma categoria de espíritos associada a personagens tipicamente nordestinos. Segundo Souza (2001), assumem várias facetas: o subalterno da metrópole, mas também aquele resistente às adversidades; podem vir como figuras mansas, tranquilas, pacientes e preguiçosas que só bebem água de coco e não fumam, mas podem aparecer, por outro lado, como guias irreverentes, encrenqueiros, brincalhões e valentes, que fumam, pedem cachaça e batida de coco. Souza apresenta ainda os tipos de trabalhos que se dispõem a realizar, inclusive aqueles recusados por pretos-velhos e caboclos, tais como de ordem financeira ou ligados à intimidade, como adultério e desavenças.

Souza defende que estão associados ao trabalho árduo, pobreza, analfabetismo, bairros periféricos e vida precária. De acordo com o mesmo autor, alguns umbandistas afirmam que os baianos, em suas vidas anteriores, foram nordestinos pobres, brigões, pais-de-santo do candomblé da Bahia, macumbeiros; outros acreditam que eles foram negros ou mestiços de africanos com grande experiência; confundem-se com o baiano migrante do meio urbano paulista e o negro ou mulato das cidades litorâneas da Bahia (Souza, 2001).

Concone (2006) descreve o baiano como um desdobramento do preto-velho, qualificando-o como "preto jovem" ou "mulato": "encontraremos no Baiano não apenas o Preto Jovem, mas sobretudo o mestiço, o mulato e o migrante" (p. 19).

Além disso, Concone (2006) também define o baiano da umbanda a partir de aspectos típicos a ele associados, tais como a alegria, a festa, a briga, a malandragem, o sotaque baiano, a ginga do corpo, o xaxado, a postura ereta, porém descontraída.

Para Brumana e Martinez (1991), o baiano expressa-se como "de trato ainda mais acessível do que o preto velho" ( $\mathrm{p}$. 280), é tratado com maior "intimidade" por "tu", pede para fumar e beber, não repreende seus cliente ou agentes e assume um tom jocoso em suas conversas com os consulentes.

De modo complementar a essa caracterização, alguns autores defendem que o histórico desse personagem religioso correlaciona-se com os processos de mudança sofridos pelo contexto social brasileiro em décadas recentes. Nesse sentido, deve-se destacar que o baiano é, sobretudo se comparado às entidades mais tradicionais e fundadoras do panteão umbandista, um "espírito novo" nos terreiros, e, segundo Souza (2001), surgido nas décadas de 1950 e 1960, quando ocorreu forte fluxo migratório de nordestinos para o estado de São Paulo, principalmente para compor o quadro urbano de trabalhadores não qualificados das construções civis e dos diferentes ramos da indústria automobilística então em grande expansão, especialmente devido à política de Juscelino Kubitschek na segunda metade da década de 1950 voltada à industrialização, à abertura da economia, ao capital estrangeiro e à construção de novas rodovias ligando as demais regiões ao Centro-Oeste e ao Sudeste do país.

De modo semelhante, Concone (2006) faz o mesmo tipo de relação: "Assim, é inegável que o crescimento da categoria do Baiano em São Paulo acompanhou o crescimento da migração interna e o Baiano, na verdade, é a imagem do migrante nordestino; uma síntese" (p. 19). Brumana e Martinez (1991) aproximam-se dessa tese, acrescentando a "hipótese de que as entidades umbandistas não são criações 'ex nihilo' do culto e sim a absorção de significantes preexistentes em diversos registros culturais" (p. 257).

Na mesma linha, Negrão (1996) argumenta que o universo simbólico da umbanda "foi elaborado de forma popular, espontânea, como reflexo imediato da vivência de seus elaboradores" (p. 28). Já para Ortiz (1978) esta ligação existe, mas não parece tão imediata, uma vez que o autor afirma que a umbanda se constitui em um processo de diálogo com mudanças sociais brasileiras, de modo que a análise de sua origem deve se referir dialeticamente às transformações sociais do país. Tese que se pode compor com a de Trindade (conforme citado por Negrão, 1996), segundo a qual os tipos do panteão umbandista são uma construção mítica destinada a conferir "sentido a um universo social sem significado, como tentativa de resolução coletiva dos problemas gerados pela vivência (...) anômica, dos grandes centros urbanos nas décadas iniciais do século" (p. 37). Segundo Trindade (2000), em narrativas umbandistas "estão situados os quadros sociais de referência em que se constrói a memória coletiva" e agrega que "as estruturas dessas narrativas são homólogas às encontradas na construção da memória, ambas operam segundo o processo de bricolagem, de recombinações de elementos extraídos da história vivida" (p. 160). Para Prandi (1991) a umbanda "é um palco do Brasil" (p. 88) e segundo Bairrão (2004) "o sagrado umbandista, ao proporcionar uma imagem de si, também cuida e repara a imagem social de setores atingidos por discriminações e estigmas ferozes" (p. 72). 
Além de buscar caracterizar a categoria espiritual "baiano" por meio de suas formas de expressão ritual e narrativas míticas, esta pesquisa tem também como objetivo desvendar como a umbanda elabora e incorpora ao seu panteão vivências humanas e tipos sociais brasileiros, tais como os descritos neste artigo.

\section{Método}

\section{Participantes}

Participaram guias espirituais baianos (os médiuns "incorporados" por eles) de terreiros de umbanda, dentre os quais neste artigo se referem depoimentos dos seguintes: Baiana Sete Saias Verdes e Baiano Zé da Faca, da Tenda de Umbanda Cacique Pele Vermelha; Baiana Redonda e Baiano do Coqueiro, da Casa Estrela do Mar; Baiano Zé do Coco, Baiana Maria Conceição e Cangaceira Jurubeba, da Fraternidade Espiritual Caminhos de Oxalá; Baiana Teresa, da Casa de Caridade Mãe Maria; e Baiana Maria do Coco e Baiano Juarez, do Terreiro de Umbanda Oxalá e Iemanjá.

\section{Procedimento}

\section{Coleta de dados}

Foi realizado um levantamento bibliográfico da literatura científica pertinente ao assunto e para o trabalho em campo utilizou-se o método etnográfico - observação participante e registros em notas de campo - além de entrevistas semiestruturadas com médiuns em estado de transe.

\section{Análise dos dados}

Segundo Bairrão (2001), a psicanálise pode ser útil em estudos sobre fenômenos que, em sua essência, são psíquicos e sociais, mas também religiosos, desde que o pesquisador seja cauteloso quanto ao risco de reducionismos e evite achatar o acontecimento sagrado. Não se trata de "psicologizar" a vivência do sagrado na tentativa de "traduzi-la" em significados prontos e extrínsecos ao fenômeno religioso, mas desenvolver "pesquisas nas quais interessa dar voz a sentidos presentes e memórias abafadas do sujeito social" (p. 12).

Para a análise dos dados foi utilizada a psicanálise lacaniana e em particular o conceito de significante. Em rituais de possessão, tal qual a umbanda, não há um idioma estritamente reduzido ao verbal, e sim uma composição rica em sons, sabores, sensações, movimentos, vivências e narrativas. Todos esses elementos enunciam algo e constituem-se como um dizer. Por isso o significante, independentemente de seu substrato material, é sempre o representante do sujeito para outros significantes (Lacan, 1988/1966) e não se concretiza exclusivamente em palavras, sendo significante tudo aquilo que, em determinado contexto, produza e faça sentido.
Foi realizada uma etnoanálise (termo proposto por Mageo, 1996) mediante a identificação dos significantes que se repetem nas narrativas (com acento em especial no modo como se produzem), a busca de onde estão implícitos, em que ponto se entrecruzam, se recombinam e a trajetória desse trânsito simbólico da história e geografia para as narrativas míticas de possessão da umbanda.

\section{Considerações éticas}

As entrevistas foram gravadas após o devido esclarecimento sobre a pesquisa e seus objetivos e mediante a assinatura de um Termo de Consentimento Livre e Esclarecido. O Projeto referente aos resultados e análise deste artigo foi aprovado por Comitê de Ética em Pesquisa da Faculdade de Filosofia, Ciências e Letras de Ribeirão Preto da Universidade de São Paulo (172/2005 - 2004.1.1567.59.0.).

\section{Resultados e Discussão}

\section{O personagem itinerante e os seus ingredientes rituais}

Na umbanda a linha espiritual dos baianos inclui personagens típicos da Bahia bem como quaisquer outros tipos populares caracteristicamente nordestinos. O baiano é comumente solicitado quando a situação apresenta-se incontornável, quando se trata de "coisa pesada". Apesar de seu surgimento relativamente recente, este guia rapidamente se generalizou, tornando-se hoje muito requisitado.

Muitos umbandistas se identificam com os baianos pelo seu tom descontraído e alegre, que deixa o consulente à vontade; e pelas narrativas míticas marcadas por dificuldades e superações. Neste caso, optou-se por transcrever os relatos dos médiuns conforme a linguagem por eles empregada.

A Baiana Sete Saias Verdes define a sua própria linha:

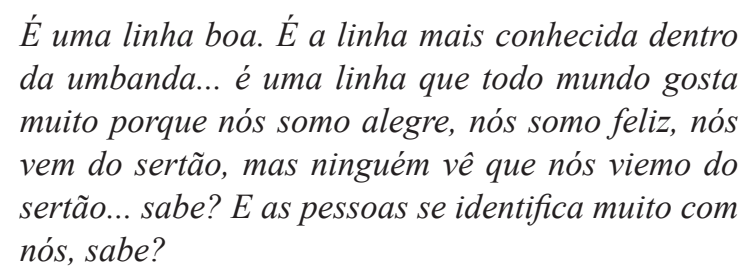

A Baiana Teresa revela uma história de sofrimento e coragem: "Óia... fia... é uma longa história... de uma tristeza sem fim... onde não se tinha nada pra se comer... era onde assim... painho pegava toda a fiarada e pois se ia...".

Durante a gira de baianos, estes personagens, incorporados em seus respectivos médiuns, compõem-se mediante significantes que se combinam e se entrelaçam como ladrilhos de um mosaico: a cana-de-açúcar, o coqueiro, o coco, a batida e a água de coco, a pimenta, o caju, a mandioca, a farofa com feijão preto e carne seca, o chapéu de couro e o 
chapéu de palha, a vela amarela, a peixeira - ou facão - e a colher de pau. Cada um revela sua função simbólica e cada combinatória caracteriza um tipo diferente de baiano. Os seus principais significantes apresentam-se abaixo, agrupados de acordo com seus usos e sentidos e referidos por meio de versos de pontos cantados - músicas rituais.

\section{Meu facão bateu embaixo, a bananeira caiu}

A faca define, principalmente, o subtipo do cangaço. O cangaceiro pertence, em alguns terreiros, à linha dos baianos. Em outros, derivou-se numa nova linha.

É uma linha ligada aos baianos, sabe? Só que é na riscada da faca... sabe? Se a coisa não consegue resolvê nada, então nós puxa o cangaceiro, que o cangaceiro vira a banda e resolve a coisa, sabe? Porque muitas vezes você não tem permissão pra virá a banda... não tem permissão pra trabalhá com a outra banda... (Sete Saias Verdes).

Os baianos são geralmente entendidos como uma "linha intermediária", isto é, situada a meio termo entre o polo celestial das crianças, caboclos e pretos-velhos (direita) e o polo terreno dos exus e pombagiras (esquerda), sendo que em particular o cangaceiro pode transitar entre estes de maneira mais explícita ("virar a banda"). É muito comum o médium, incorporado por um cangaceiro, atender os consulentes com um facão em punho. A peixeira define a linha, o limite; delineia limiares, fluidos e oscilantes.

A faca, o facão e a peixeira figuram cortes polissêmicos. A peixeira pode ser utilizada para cortar a "coisa feita", romper o mal, como um significante associado à linha do cangaço, uma "linha mais forte", evocada quando a questão não é resolvida com facilidade, tal como no trecho acima. Por outro lado, o facão cangaceiro também corta literalmente:

Então eu falo assim... com a peixeira na mão... "tu cala a boca, porque se tu for gritando, eu vou enfiando...se tu gritá mais alto eu enfio mais...se tu não gritar eu só vou riscar'... apois então elas não gritava... apois só fazia amarrar e deixava lá... (Maria do Coco).

A faca também pode ser utilizada para punir: "Baiana trabaia pra Sr. do Bonfim, mas baiana quer catá a peixeira... mas não é matá não, bichinha, mas dá uns corretivo assim mais forte... balançá o coqueiro mais forte..." (Maria do Coco).

O facão pode ainda afigurar-se um utensílio milagroso de cura: "Por isso Baiana faz usador dessa primeza de Baiana... onde a ponteira é milagrosa, mas ela também tem o poder de curar e de tirar a maldade, que cá nessa terra chama-se facão" (Teresa).
O facão mata e cura, revela o caráter fluido e intermediário dos baianos, a quem é possível usar um artefato cortante para diferentes fins: delinear e definir-se, romper o mal, punir, matar ou, complementar e paradoxalmente, curar.

Pisa, baiano... pisa lá que eu piso cá...

A composição do contraditório é vivenciada, em ato, em significantes que ilustram a ginga de pisada dúbia. $\mathrm{O}$ baiano dança em um ritmo caracteristicamente nordestino, o xaxado (um pé lá, um pé cá), em uma pisada firme, porém na cadência de um movimento cambaleante, uma ginga oscilante, reveladora da maleabilidade da linha.

Outro indicador desse aspecto paradoxal refere-se a dois modos dos baianos se mostrarem através da maneira como falam e de seus pontos cantados, ora apresentando-se festeiros e malemolentes: "Quando eu entro numa farra, não quero sair mais não, vou até o Farol da Barra, apanhar o sol com a mão"; ora aguerridos e muito ligeiros: "Baiano bom, baiano bom, baiano bom é que sabe trabalhar, baiano bom é que sobe no coqueiro, tira o coco, bebe a água e deixa o coco no lugar".

Significantes aparentemente contraditórios, em trabalho de baiano, se completam e alternam: "Se baiano tem vontade de fazê descarrego, ele risca fogo no chão... se baiano resolve na conversa... na água de coco e na dança... é ali que ele faz o descarrego..." (Redonda). O Baiano do Coqueiro, por exemplo, trabalha em parceria com o Baiano da Candeia. Este, apesar de ser das Candeias, na falta de luz é bom de briga:

Olhe... oxe, sujeito... olhe... oxe... eu ainda vou lhe dizê... quando esse candeeiro se apaga, oxe, ai quem pode mais chora menos... tu entende? E assim eu tenho meu companheiro que é um grande companheiro meu, que é o Baiano da Candeia... oxe... sujeito... quando apaga o candeeiro, como ele diz, é lapada pra todo lado... (Baiano do Coqueiro).

A luz da candeia - luz quase sempre indica evolução espiritual - também pode significar ter vindo à luz (estar vivo) e o apagamento do candeeiro significar o apagamento da vida (na acepção de vida apagada, sem brilho, espelhada e sancionada simbolicamente pela ideia de "morte por encomenda", do ponto de vista simbólico provavelmente direito e avesso do mesmo processo subjetivo). Mageo (1996) argutamente reconheceu na possessão em Samoa algo semelhante a este tipo de ardil subjetivo, pelo qual uma verdade (inconsciente) se vê espelhada nas ações de terceiros espirituais, ao afirmar que "a vitimização na possessão pode ser uma camuflagem da agência" (p. 76).

O caju, da mesma forma, aponta para a ambivalência da linha dos baianos: a aparência madura e sedutora do caju pode ser enganadora. 
Ele tem as duas cara... a coisa boa de se comê... quando a castanha é madura... e tem o lado ruim, quando ele tá amargo, que tu acha que ele tá lindo, que ele tá amarelinho e que a castanha é verde, né? Se mordê é um veneno... é meia perigosa, ela dá um estrago, vice? Se o cabra não for bom de coco, ele balança... (Zé da Faca).

Comida ritual também elicia essa possibilidade dos baianos se mostrarem meio cá meio lá. A Baiana Maria Conceição pediu à sua médium para preparar uma comida preta $\mathrm{e}$ vermelha, cores associadas a exu e pombagira. A comida era uma farofa, feita com azeite de dendê (o que dá uma coloração amarelada, associada aos baianos), feijão preto e carne seca (de cor avermelhada).

\section{O Sol da Bahia queimou, queimou, deixa queimar}

Tal como o fogo, outros significantes como o sol, o amarelo e a pimenta são associados ao baiano e todos apresentam a mesma propriedade: o calor. Os próprios espíritos mencionam que baiano gosta de trabalho forte, de trabalho quente. Essa “temperatura" pode surgir em campo, não apenas como um dado ilustrativo, mas como uma sensação tátil, quando há algo que de fato esquenta e queima. Indagado sobre quem são os baianos da umbanda, Juarez responde em ato, no corpo, na pele que arde concretamente:

Vou quemá você! Tape os óio! Deixe de sê frôxa! Veja como não acontece nada com meu cavalo! (deslizava, sobre o braço do médium, um conjunto de sete velas acesas, permitindo que a cera quente pingasse sobre a pele) Viu? Agora é sua vez.

Juarez exime-se de descrever em palavras quem é o personagem baiano, para sugerir sua apreensão em vivência sensorial, ou seja, há algo que não se explica verbalmente, sente-se.

\section{O coqueiro do Norte tá balançando... é a Bahia que tá chamando}

Os relatos dos baianos deixam implícito que um sentido do coqueiro é significar o próprio homem, resistente aos balanços, e em particular ser o coco a cabeça. Porém o seu uso metafórico ressignifica qualitativamente o humano e vai bem além disso. O significante coco é utilizado para definir o baiano: num contexto de sol intenso e pouca água, a casca espessa e dura guarda um líquido quase sem gosto, sendo ele, entretanto, a água que nutre, sustenta, cura, restabelece. O baiano só é "duro" por fora. Enquanto a doçura da água pode sugerir afeto e vida, a rijeza da casca insinua a força e a resistência nordestina. Embora singela, é em sua transparência que se retiram as "mirongas" e se fazem muitos trabalhos do povo baiano da umbanda:
O coco, moço... é um símbolo...é um dos símbolo... o coqueiro é um dos símbolos dos nordestino... o coco, se tu vê... uma pessoa pode passá muito e muito tempo só com um coco, só com a água do coco, só com o coco... e dentro do coco, tanto do verde quanto do maduro... tem todas mironga... todo o espaço... porque o coco... se tu pega o coco maduro e tu abre ele, ele parece com a terra, o redondo... e como eu lhe falei, dentro tem toda a água, todo o sustento... do coco tu tem a vida... certo? Zé do Coco, moço, porque simplesmente eu fui colocado nesse mistério, não tô... não que na minha terra eu era o rei do coqueiro, essas coisa não... é que eu tenho meus fundamento no coco mesmo... tá certo? (Zé do Coco).

À pergunta “Quando a senhora diz 'eu sou uma baiana', o que isso quer dizer?”, Teresa responde:

Baiana sente muito glorificada de ter vindo da raiz mesmo da Bahia, que é maior.. o coco de baiana dá em qualquer lugar...mas ele dá diferente, né? Ele não dá o mesmo coco, porque baiana muitas vezes cá na terra vê um bichinho que quer ter um coqueiro de baiano mesmo... e ele já bota lá na terra...mas ele não sabe que aquilo lá não é daquela maneira... (Teresa).

Teresa esclarece o que é "ser baiana", destacando o significante "coqueiro". Segundo Teresa, é uma planta que dá em qualquer lugar, possivelmente porque floresce em solo seco e arenoso. Porém, diz ela, não se trata de qualquer coqueiro, pois aquele que dá o "fruto de baiano" exige uma “terra preparada", um "lugar" específico.

Esse trecho permite entender o poder da metáfora em transformar significantes da vida concreta em sentidos espirituais e míticos. Neste caso, Teresa identifica-se com o coco. O baiano é o coco, é o coqueiro. Aquela árvore típica dos litorais nordestinos, que nasce em qualquer solo, assume um sentido espiritual e metafórico; um significante que também assinala uma interpretação da natureza dual do espírito nordestino na umbanda: um revestimento duro, uma aparência embrutecida, uma casca grossa de valentia e bravura; mas que internamente é doce água.

Dada esta natureza metafórica, impõe-se uma pergunta: como a experiência social e o ambiente natural do Nordeste podem proporcionar-se como significantes e comporem-se em um cenário mítico de um panteão religioso? Será o caso de analisá-lo tal como um processo de bricolagem e recombinações de elementos da história vivida, tal como propõe Trindade (2000)? É possível responder a essa questão, tal como propõe Negrão (1996), apontando que o imaginário religioso umbandista reflete imediatamente vivências sociais concretas? 
A fim de elucidá-lo, descrevem-se em seguida dois tipos característicos de personagens nordestinos da umbanda, associáveis à "água-de-coco com a rede de dormir ou à peixeira com cachaça" (Souza, 2001, p. 316), posto que os baianos parecem oscilar entre eles.

\section{Reflexão imediata ou mediata?}

Ao revelar seu caráter flexível e suas possibilidades de ginga entre as diferentes esferas místicas do ritual umbandista, alguns espíritos baianos apresentaram-se mais próximos da direita (tipificados neste trabalho pela figura do "benzedor") e outros da esquerda (cujo tipo geral aqui se refere como "jagunço").

Se alguns baianos são mais semelhantes aos "benzedores" e outros mais próximos dos "jagunços", é possível sugerir que esse personagem, de um modo geral, não se define em uma imagem única.

O típico baiano "benzedor" é um personagem nordestino que se caracteriza pela doçura dos engenhos de cana-deaçúcar no litoral (zona da mata), relata sua história de forma mansa e tranquila, pede água de coco e cerveja, personificando a figura de um sábio curador e espiritualizado.

Por outro lado, o característico "jagunço" é o tipo do "justiceiro", sobrevivente do sertão caracterizado pelas criações de gado, cujo trabalho associa-se à "morte por encomenda" (metaforicamente, ratifica a morte do espiritualmente "morto"). Mostra-se valente, irreverente, solícito em atender ou pelo menos refletir os desejos mais íntimos e menos confessáveis dos fiéis, sem censura.

Para ilustrar esses personagens, serão apresentados, em seguida, histórias e significantes rituais que apareceram em algumas entrevistas.

Maria do Coco traz em seu nome um significante que, juntamente com coqueiro e rede, compõe muitas narrativas míticas da umbanda, nas quais figuram descrições de cenários litorâneos, o que poderia remeter à figura doce e serena do "benzedor". Não obstante, essa baiana é uma personagem muito próxima do tipo do "jagunço" dos sertões nordestinos. Ela conta que trabalha com "morte por encomenda". Esclarece que, apesar de se chamar Maria do Coco, iguaria baiana normalmente associada às praias, foi "em vida na terra" uma cangaceira, em um contexto de seca e fome.

Um segundo exemplo revelador dessa flexibilidade é a história do Baiano Juarez, que narrou a paisagem onde teria habitado em vida: uma paisagem seca, onde existiam criações de animais, cenário associado ao "jagunço". Porém Juarez narrou-se como um benzedor, contou que trabalhava com cura e cuidava das pastagens e do gado. O Baiano Juarez era um curandeiro, mas não dos canaviais litorâneos, paisagens de mares, coqueiros, sombras e redes, e sim em uma paisagem embrutecida pela seca do semiárido sertanejo.

Pode-se mencionar ainda a história do Baiano do Coqueiro, que narrou ter vivido nos litorais nordestinos, cenário típico dos "benzedores" ("meu campo é na beira da praia, sujeito... deitado numa sombra de um coqueiro bem formoso..."), mas em contrapartida esclarece que os seus "métodos" de trabalho são a "rastêra" e o "saculejo" e que trabalha em parceria com um "cumpade" (exu). O Baiano do Coqueiro dissocia-se da imagem baiana da preguiça, tranquilidade e serenidade, ligada às paisagens litorâneas de coqueiros e redes. Fala que o seu trabalho deve ser feito com rapidez ("ligerêza") e pressa.

Além da zona da mata e do sertão, o Nordeste brasileiro apresenta ainda uma terceira região, intermediária, o agreste. Trata-se de uma zona de transição, despida de identidade rígida e bem definida, pois não é o litoral açucareiro, nem o sertão vaqueiro. Do mesmo modo, o cangaceiro, o tipo de baiano mais assíduo entre os terreiros participantes (a ponto de por vezes se destacar como uma linha autônoma), revela esse caráter intermediário. De fato, o cangaceiro, enquanto personagem histórico do Nordeste (e não apenas como entidade espiritual), não se fixava em lugar algum, vivia em grupos itinerantes, que perambulavam pelas regiões nordestinas, fugindo da polícia (os "canela preta"), em busca de justiça social, vingança e saques. Na umbanda, ele figura o insurgente, o bravo resistente às adversidades do cenário sertanejo e na vida dos seus adeptos. Nesse sentido, o cangaceiro da umbanda, exatamente por oscilar entre tipos que em si mesmo já são intermediações (a linha dos baianos), na sua falta de identidade ou pelo menos de fixidez, exponencia este traço estilístico da composição da baianidade umbandista, o transitar.

Com base nesses dados, seria inconsistente supor que há, entre aspectos geográficos e sócio-históricos nordestinos e as entidades baianas do panteão umbandista, uma reflexão direta e imediata. Essas entidades não se apresentam categorizadas em tipos simples e puros. Reúnem significantes associados a diferentes aspectos históricos e geográficos nordestinos, em inumeráveis recomposições. O que há é uma combinatória de significantes que desconstrói a noção de um Nordeste (num sentido místico e simbólico) "pronto" e "acabado". Essa bricolagem de características nordestinas sugere um Nordeste interpretado enquanto "processo", constituído historicamente e na memória por fissuras, crostas e inúmeras camadas de tintas, em mistura, sem que se defina um único novo tom.

A hipótese de que haja uma reflexão entre aspectos concretos de um contexto geográfico e sócio-histórico nordestino e as narrativas míticas dos baianos da umbanda pode ser pensada como mediata, ou seja, indireta. Algo se interpõe, misturando as "tintas significantes", recombinando-as. Presumivelmente essa reflexão refere-se não apenas ao Nordeste, enquanto região geográfica, ou ao nordestino, enquanto migrante e residente das periferias urbanas do Sudeste, mas sobretudo à cultura e espiritualidade nordestina, que viajaram com o migrante, trazendo costumes, crenças, histórias, tradições. 


\section{Travessia histórica e itinerâncias metafóricas}

No intuito de ilustrar a reflexão mediata de aspectos sócio-históricos da região Nordeste em narrativas míticas de espíritos nordestinos da umbanda paulista, relatam-se em seguida trechos da história da Baiana Teresa, que ecoam a luta nordestina pela sobrevivência em um cenário de hegemonia dos brancos sobre terras que historicamente foram utilizadas para as criações de gado e para a busca de ouro e de esmeraldas, às margens dos rios do interior:

Tinha muita coisa bonita... fia... mas aonde tinha os seus dono... e nós não podia chegar perto nem pra poder fazer olhador e sentir um pouquinho do que é de bom na natureza... um pouquinho de bom das coisa bonita...Pois se ia fazer a procuradora da pedra preciosa... aonde se vivia dentro das grande água parada... aonde tudo era caburequito pequeno... e ficava assim a cavucar com o pé... pegava-se a peneira e fazia erguedor... e se não achava-se nada... era de vez em quando que achava alguma coisa... e só que uma lua foi se encontrado uma pedra grande... preciosa... e houve outra tragédia...nessa luta toda... ele (o pai da Baiana, um garimpeiro) também foi pro lado de Nosso Senhor de uma maneira muito cruel... foi feito o enforcador... aonde ele pôde soltar a pedra... perdeu a força das mão e soltou a pedra e os inimigos foi-se embora... e mainha ficasse tudo com fiarada... Baiana que era maior é que trabaiava... deixou de procurar a pedra e foi pela lavoura (Teresa).

Em seguida, na narrativa de Teresa surgem menções a um processo de desapropriação do sertanejo, de conflitos e desigualdades sociais e de uma realidade constituída por injustiças: "O que existe nessa terra... a inveja... o poder... só tem, muitas vez, o benefício aquele que tem as coisa... quem não tem tá sempre lá no fundo do poço... por isso que Baiana entrou nessa vida da tristeza... mas pra fazer a justiça com a própria mão...".

Na sequência, a Baiana revela o contexto de vinganças, insurgências e ressentimentos, que, se por um lado foi responsável pelo extermínio de parte significativa de indígenas e sertanejos, por outro parece marcar a história de uma população nordestina, de geração em geração. Bem como, com base nesses conteúdos significativos, veicular uma condição humana de subalternidade social e inconformismo, que em larga medida se perpetua nas condições de existência contemporâneas dos "filhos" espirituais destes baianos, médiuns e demais seguidores do culto.

Baiana se vingou de quem tirou a vida de painho... Baiana não deixou aquieto não... Baiana fez a mesma coisa que fizeram com painho... (...) Porque Baiana também foi estrangulada... entonce é de antepassados e antepassados que vem essa desarmonia... que vem nessa terra... e já existia... entonce aconteceu isso com muita dor... (Teresa).

À expressão na forma de enredo mítico da saga e tragédia de indígenas nordestinos e possivelmente da sua descendência cabocla, se soma, no trecho a seguir, uma referência a um feitor, o que pode compor o anteriormente dito com a memória de outro personagem da composição social e histórica nordestina:

Esse feitor era um cabra da peste muito maldoso... que painho de Baiana atrabaiava prum homem branco de poder na terra e quem mandava as ordem era esse feitor... esse feitor.. baiana ajuntou-se num grupo e tirou a vida dele por tanta injustiça que ele praticou na terra... (Teresa).

Feitores são personagens que compõem o cenário da escravidão brasileira. O feitor é o outro do conflito, o perseguidor, e aqui se torna um novo personagem sertanejo, na figura do branco ou do mestiço subalterno e empregado dos senhores da elite. Aparece na narrativa sem dispor do monopólio da palavra, somente porque está marcado na história do Nordeste e do Brasil, no caso por meio do enredo mítico de um espírito que teria sido oprimido por ele.

Tal como sugerido por Mageo em Samoa (1996, 2002), também na umbanda parece haver uma intertextualidade, um trânsito simbólico em que cenas de vidas concretas plausíveis - expressas numa linguagem denotativa referencial - contam mais do que falam, isto é, passam a dizer mais do que o seu significado literal, expressam-se em uma linguagem simbólica e como vocabulário religioso nas narrativas míticas.

Ainda assim resta saber que processo será esse capaz de mediar a "migração" de aspectos concretos da tradição espiritual e histórica nordestina, até o seu aparecimento e transformação em significantes rituais nas giras de umbanda.

\section{Jurubeba traduz-se em metáforas}

A tradição sócio-histórica nordestina, bem como os aspectos geográficos do Nordeste, recombina-se em significantes. Modos de vida aparentemente insignificantes passam a veicular um sentido não mais regional ou particular e deixam de ser descrições estritamente objetivas. Cenários da vida natural, as danças, as músicas, a vegetação, o relevo, o clima, o contexto histórico e o próprio estilo narrativo transformam-se em significantes e símbolos religiosos com vocação universal, mediante a sua transmutação em metáforas (tais como o Norte do "Coqueiro do Norte" como orientação divina, norteamento espiritual) e metonímias (a solaridade nordestina como alusão à luminosidade espiritual, por exemplo).

Jurubeba, "espírito" de uma cangaceira, exemplifica esse processo de transformação de aspectos descritivos de 
cenários histórico-geográficos do Nordeste, primeiramente, em metonímias do caráter de personagens do panteão religioso muito humanos, utilizadas para a composição de tipos espirituais, e em seguida destes em metáforas e símbolos universais, coloridos pelo cenário nordestino.

Diante da pergunta sobre "o que é o cangaço", ela esclarece: "o povo acha que o cangaço é específico daqui... né não, meu fio... onde tem espinho, onde tem seca... é cangaço..." (Jurubeba).

Há, sem dúvida, algo que é da ordem vivencial. Jurubeba supõe-se, em sua narrativa mítica, uma personagem que experimentou vividamente algo que poderia ter sido experienciado, igualmente, por qualquer nordestino concreto, seja ele migrante ou nativo do sertão: a realidade bruta de um "cenário cangaceiro" (o espinho, a seca, a sede, o ser sertanejo). No cenário nordestino, a concretude do espinho fere, perfura, penetra, dói, o real se impõe. Pode ser o espinho concreto, mas pode ser a sensação, a vivência, o sentido do espinho. Entretanto Jurubeba garante que essa vida espinhosa não é específica do nordestino, ao explicar que onde há espinho, onde há seca, é o cangaço. Em seu dizer, a experiência concreta assume um cunho metafórico.

A seca, por exemplo, como significante polissêmico, define o cangaço: o espinho é o cangaço; a seca é o cangaço. Por isso, onde há uma vida seca, repleta de espinhos e dificuldades, vivencia-se, metaforicamente, o cangaço.

Em sua história mítica, Jurubeba conta que foi uma cangaceira, mas precisou apartar-se de seu bando porque ficou grávida e optou pela maternidade. Não se pode ser mãe e cangaceira, ela explicou. É preciso escolher, porque as crianças choram e, no cangaço, a lágrima não é permitida, pois o "seu som" denuncia a presença do bando aos "canela preta" (a polícia).

Entretanto, em uma composição contraditoriamente possível, Jurubeba narrou-se como tendo sido mãe extremosa e, ao mesmo tempo, assassina de seus próprios filhos. Em consonância com tal aspecto, através de sua narrativa, é interessante observar como a água, significante maleável e flexível - tal como a própria linha dos baianos é definida -, é riqueza escassa num cenário seco, que impõe escolhas rígidas, pouco fluidas: Jurubeba precisava optar entre ser mãe ou continuar no cangaço - "ou a lei da maternidade ou a lei da justiça"; ou se é mãe ou cangaceira.

Novamente, no fim da narrativa, a lei severa do impasse: Jurubeba opta por matar os próprios filhos a vê-los chorar de fome. Não suporta a lágrima salgada do choro da criança, o afeto, a emoção fluida da água. O cenário é seco (não há água), o sertanejo é seco (não há choro), a mulher cangaceira é seca (não poderia ter filhos), a vida é seca (áspera). A escolha bruta do sertão se impõe: ela mesma mata, ela mesma enterra, ela vela por eles. Por fim, a cangaceira traz, em sua voz, a essência do "ser baiano": "Tem que sabê impunhá uma faca pra pudê fazê vivê".

Jurubeba opta, define-se, não cambaleia; ela empunha a faca. Porém, com a mesma faca que garante a vida, embora mãe extremosa, ela assassina os cinco filhos. A fome, a lágrima e a dor eram a morte.

A veemência do facão, em rituais de umbanda, parece revelar o caráter severo e rígido da vida seca sertaneja, quando o limite e a escolha se insinuam. Exu é esquerda, pretovelho é direita. E o baiano? O transitório não é praia, nem sertão; não é direita, nem esquerda. É o cruzamento dos múltiplos aspectos, é o humano, o doce salgado, o salgado doce; não é apenas a paciência e humildade dos pretos-velhos; nem a altivez dos caboclos; é, sim, ao mesmo tempo, o cativeiro e a liberdade; a doçura e a raiva.

Nesse sentido, é o próprio estilo narrativo dos cangaceiros que revela sua identidade: no universo umbandista o baiano personifica o oxímoro, "aproximação de duas palavras ou de duas expressões contraditórias, que se excluem mutuamente de um ponto de vista puramente lógico; expressão de um paradoxo" (Casteleiro, 2001, p. 2706). Ou seja, não é o bastante descrever e classificar os símbolos e metáforas que se consorciam ao "ser baiano", sendo necessário acrescentar este modo típico de se proporem em frases e em construtos narrativos, como em um jogo.

Jurubeba pergunta-se "o que é a linha do cangaço?", e ela mesma responde: "São aquelas pessoas que se acham ruins demais por sê boa, ou boas demais por sê ruim...". Considerando que o sentido literal do oxímoro é absurdo, somos compelidos a buscar um terceiro sentido, que seja capaz de harmonizar os dois conceitos opostos na mesma expressão. O ruim demais, em última instância, é bom. Por ser ruim, é possível ser bom demais.

Se a vocação do panteão umbandista for iluminar a humanidade (na acepção de mostrá-la a si mesma), sem sombra de dúvida o personagem correspondente ao oxímoro (o baiano) apresenta-se como o mais próximo da possibilidade de refletir a vivência de contradições e a condição paradoxal e conflituosa que caracteriza o humano. É permitido e possível, sim, ser mãe e assassina; ser mãe e cangaceira; bom e ruim; preto e branco, sem, no entanto, definir-se um único e terceiro tom imóvel, ideal, rigidamente cinza. Enfim, a imagem de um sujeito possível.

\section{Considerações finais}

Em travessia retirante, os passos de um "caminho longo" manifestam o percurso inquieto e perambulante dos baianos em manifestações religiosas umbandistas no Estado de São Paulo. Seu movimento de cambaleio no imaginário, em um xaxado firme, porém em passo leve, suave, sublime em precisão, em dança ritmada dos múltiplos personagens carismáticos em que se apresenta. Sua ginga descontraída, que oscila entre os distantes extremos dos rituais, sua cadência nordestina contraditoriamente descompassada em pé, em corpo, em voz, em palavras sem água, em narrativas secas, em histórias nordestinas irrigadas de verbos andarilhos, metáforas itinerantes e sentidos nômades. 
Quem é o baiano da umbanda? Os espíritos de nordestinos compõem o contraditório em um cenário religioso, ora pincelando a alegria e o clima festivo e bem humorado de suas giras, ora revelando uma tonalidade mais dramática em narrativas que figuram dificuldades e superações. A natureza dual desse personagem é dita não apenas através de histórias míticas e de seu estilo narrativo enriquecido por oxímoros, mas também por meio de ingredientes rituais, distintos e muitas vezes opostos, que não têm simplesmente um uso e uma função facilmente descrita, mas devem ser vivenciados sensorialmente (o calor do fogo que queima, a pimenta que arde se mastigada, a batida de coco sorvida, o cigarro de palha tragado, a incisão da peixeira cortante, a agudez de um espinho profundo).

Boa parte do que assim é (inconscientemente) dito manifesta-se em atos rituais "silenciosos", mais para serem sentidos do que explicados. Surgem inúmeras condensações, metáforas (na acepção lacaniana) que se apresentam na forma de combinações marcadas pelo registro histórico, pela memória significante de combinações.

Uma narrativa como a da Baiana Teresa permite inferir um rearranjo desses aspectos, que tanto podem compor e associar o nordestino, menos ao senhor branco do que ao europeu pobre ou degredado (vide os nomes latinos e de santos católicos associados aos espíritos nordestinos da umbanda), como ao nativo "dócil" e ao "arredio"; bem como ao escravo, historicamente perseguido por feitores; ou ainda ao próprio negro brasileiro, o quilombola que também é um insurgente, ou o filho de africanos escravizados, o baiano "preto jovem". Em última análise, o drama que aparece imediatamente aludido nessa narrativa mítica resgata a memória dessas figuras humanas historicamente significativas na composição da humanidade brasileira e sua miscigenação, sobretudo simbólica. O seu enredo não se associa apenas à trajetória de um personagem popular específico, mas ao enredo histórico da população sertaneja como um todo, às suas experiências sociais, que se compõem de significantes de múltiplas origens; o que favorece a presença de sobreposições conflituosas, que por sua vez possibilitam a expressão de outros conflitos, atuais, cuja enunciação possa compor-se com os mesmos significantes históricos, ou, mais precisamente, mediante a utilização de reminiscências coletivas estruturadas em enredos míticos.

Cada significante comporta muitas histórias, é um dom e uma cicatriz. Tem uma origem, vem de um ancestral, compõe cenários e abre rumos; mas também, contraditoriamente, provém de uma dor, de um impacto, de algum trauma social ou histórico, remetendo a marcas herdadas. Em síntese, quando a história mítica de um espírito reverbera "involuntariamente" fatos históricos e descrições geográficas, revela-se a memória, imprime-se o tempo.

É importante destacar que os significantes não podem ser reduzidos às palavras que aparecem nas narrativas dos baianos, já que lhes são anteriores na forma do cenário geográfico nordestino entremeado ao contexto sóciohistórico. Fazem-se transportar no próprio corpo e nas vivências sensoriais, reaparecem em comidas e bebidas, roupas, ritmos etc.

Se for o caso de retomar a tese que relaciona o surgimento dos baianos nos rituais de umbanda ao processo migratório de nordestinos para o Sudeste, é preciso acrescentar que tais migrações, menos e mais do que processos demográficos, são "migrações de significantes", ou ainda "migrações significantes". O deslocamento dessa população é significante de deslocamentos de significantes.

Os aspectos de vivências regionais nordestinas mostram-se significativos para os fiéis - sejam eles baianos, pernambucanos, cearenses ou paulistas - e se transformam em metáforas de verdadeiras epopeias humanas e místicas. As metáforas são, dessa forma, redescobertas na essência intrinsecamente significante dos espíritos e na composição estilística de suas narrativas. Cenários geográficos destacam-se em metonímias, que por sua vez se permutam em metáforas, transformando em sentidos transcendentes o que poderiam ter sido regionalismos aleatórios. Não há portanto reflexão direta da vida social e da memória coletiva. Tipos populares sofridos que apresentam aspectos de identificação com biografias populares comuns, vidas aparentemente insignificantes e supostamente inconsequentes, transmutam-se num tipo de mensageiro de um Norte espiritual aclimatado simbolicamente à paisagem dos coqueiros e à solaridade do sertão. Ou seja, não apenas os nordestinos migrantes se inserem no contexto social paulista e são "acolhidos" e sacralizados no imaginário umbandista, que lhes concede um espaço no panteão (a linha dos baianos), como também é possível pensar que é o próprio imaginário religioso que se apropria do Nordeste, em proveito da sua vocação para repercutir novas necessidades de significação.

A significância do Nordeste interioriza-se numa topografia espiritual que concede sentido à síntese de um ancestral brasileiro e o situa como mediador de extremos compossíveis, nem sempre celeste, nem só terrestre. A umbanda não poderia deixar de fora o indefinido e o ambíguo, tão familiar à real condição humana e irredutível a uma dicotomia entre uma direita celestial e uma esquerda terrena. Na medida em que outros tipos espirituais desde o início ou progressivamente se destituíram de verossimilhança humana (a exemplo do preto-velho, cada vez mais distante da lembrança dos últimos escravos à medida que se rarefaz em atmosferas mais elevadas e se retira para camadas de tempo mais augustas e profundas), com este jovem personagem a umbanda devolve aos fiéis a alegria de viver e de serem contraditórios, humanamente possíveis, através dos "novos pretos" que são os seus baianos.

O personagem baiano parece dar conta dessa lacuna, atendendo à premência de misturar as tintas, algo como um pincel, autor e artista de uma mescla de cores e as traduzindo em novos tons inacabados e indefinidos, para que nunca cesse o cambaleio e o gingado. A sua "missão" ou vocação parece ser antropomorfisar nas narrativas e rituais umbandistas o oxímoro, para aí inscrever e poder expressar o acontecer humano. 


\section{Referências}

Assunção, L. C. (1999). O reino dos encantados, caminhos, tradição e religiosidade no sertão nordestino. Tese de doutorado não-publicada, Pontifícia Universidade Católica de São Paulo, São Paulo.

Bairrão, J. F. M. H. (2001). A imaginação do outro: Intersecções entre psicanálise e hierologia. Paideia, 11(21), 11-26.

Bairrão, J. F. M. H. (2004). Sublimidade do mal e sublimação da crueldade: Criança, sagrado e rua. Psicologia: Reflexão e Crítica, 17(1), 61-73.

Brumana, F. G., \& Martinez, E. G. (1991). Marginália sagrada. Campinas: Ed. Unicamp.

Casteleiro, J. M. (2001). Dicionário da língua portuguesa contemporânea da Academia das Ciências de Lisboa (Vol. 2). Lisboa: Verbo.

Concone, M. H. V. B. (2006). O ator e seu personagem [Versão eletrônica]. Revista Nures, 2(4), 1-34. Recuperado em 18 fevereiro 2011, de http://www.pucsp.br/nures/revista4/ nures4_mariahelena.pdf

Lacan, J. (1998). Escritos. Rio de Janeiro: Jorge Zahar. (Original publicado em 1966)

Mageo, J. M. (1996). Spirit girls and marines: Possession and ethnopsychiatry as historical discourse in Samoa. American Ethnologist, 23(1), 61-82.

Mageo, J. M. (2002). Intertextual interpretation, fantasy and Samoan dreams. Culture \& Psychology, 8(4), 417-448.

Negrão, L. N. (1996). Entre a cruz e a encruzilhada: Formação do campo umbandista em São Paulo. São Paulo: Ed. USP.

Ortiz, R. (1978). A morte branca do feiticeiro negro. Petrópolis, RJ: Vozes.

Prandi R. (1991). Os candomblés de São Paulo. São Paulo: Hucitec.

Souza, A. R. (2001). Baianos, novos personagens afrobrasileiros. In R. Prandi (Org.), Encantaria brasileira: $O$ livro dos mestres, caboclos e encantados (pp. 304-317). Rio de Janeiro: Pallas.

Trindade, L. (2000). Conflitos sociais e magia. São Paulo: Hucitec.

Alice Costa Macedo é Mestre pelo Programa de Pós-graduação em Psicologia da Faculdade de Filosofia, Ciências e Letras de Ribeirão Preto da Universidade de São Paulo.

José Francisco Miguel Henriques Bairrão é Professor Doutor do Departamento de Psicologia da Faculdade de Filosofia, Ciências e Letras de Ribeirão Preto da Universidade de São Paulo. 